\title{
マカオ旧市街の住環境を形成する袋小路の段階構成 HIERARCHICAL SPATIAL COMPOSITION OF DEAD END STREETS FOR RESIDENTIAL ENVIRONMENT IN THE OLD DISTRICT OF MACAO
}

\author{
松田 徹*, 是永 美 樹**，八木幸二***
}

Toru MATSUDA, Miki KORENAGA and Koji YAGI

\begin{abstract}
The objective of this paper is to clarify the hierarchical spatial composition of dead end streets for residential environment in the old district of Macao. It has been developed into high density city where residential and commercial areas coexist. Dead end streets as buffer zone are analyzed focusing on a hierarchical spatial composition with three levels such as urban, building and individual. As the result, four types of hierarchical spatial composition into dead end streets were pointed out.
\end{abstract}

Keywords: Macao, Dead End Street, High Dense City, Residential Environment, Hierarchical Spatial Composition マカオ、袋小路、高密都市、住環境、段階構成

\section{1. 度}

\section{$1-1$. 研究の背景と目的}

都市というものがパブリックからプライベートに至る段階的な空 間秩序によって連続的に構成されるものであるとすれば、限られた 領土の中で高密に発達し、明確な用途分化がされてこなかった不整 形なマカオ旧市街において、その全域にわたって分布する袋小路の 存在は、限られた外部空間として、また都市における住環境を成立 させる上での緩衝空間として、都市機能を担う興味深いものであ る。またかつて 2 層の住居が建ち並びその中で血族的なコミュニ ティを形成していたとされる袋小路が、近代化に伴う中高層化と住 居以外の機能の混在化にも関わらず今なお生き続けていることか ら、そこには依然マカオの住環境を成立させるシステムの存在が賽 える。

さらに袋小路に生活があふれ出していることや、ケージ*1 と呼 ばれる住民によって設置される仮設増築物が存在することは、マカ オにおいては都市の骨格を形成する都市計画的理念やその都市に生 活する住民の要求が、対立関係でも主従関係でもなく重なり合いな がら重層的な都市を形成しているものと捉えることができる。この ことからマカオは、住民の手による都市形成・地域形成の可能性を 示しているものと考えられる。

以上のような背景から本研究は商住混在都市マカオの旧市街にお いて、住居や袋小路の形態とその周辺の要素を重ね合わせて示し、 さらに袋小路を取り巻く周辺環境の特徵を示すことで、住環境を形 成する袋小路の段階構成を明らかにすることを目的とする。
ここには大きく 2 つの意義があるものと考える。

一つはマカオにおける袋小路の現状を調査・分析することによっ て今後の再開発に資する考え方を示すという立場に立つものであ る。ポルトガルによる 440 年にも及ぶ長期にわたる統治という世 界的にも稀な歴史的背景にありながら、マカオにおいても見過ごさ れがちなこのような都市の土着的側面を明らかにすることは、居住 性の継承という点において指針を与えることができると考える。

もう一つは都市空間の即物的側面に着目し、住居や街路の形態を 物理的に理解することによって、地域性を越えた一般的な高密都市 における住環境の計画概念に資することを期待するものである。

\section{1-2. 既往の研究}

筆者らはこれまで、広場のような公的外部空間の連続性を分析す ることにより、マカオにおける屋外環境の役割を明らかにしてきた ※2。本研究は、広場とは対をなすマカオの私的外部空間である袋小 路を併せて分析することによって、明確な用途分化がされずに住居 と商業という用途が混在したマカオの外部空間の、住環境としての 側面を明らかにしようとするものである。

また、高密都市における住環境についてはインドの歴史的都市で あるアーメダバードとジャイサルメルにおいて、城壁によって囲ま れた迷路状の特徵的な街路形態と住居形態との対応性を分析するこ とにより、住環境を形成するシステムを明らかにしてきた*3〜5。本 研究はマカオの袋小路を対象とした、高密都市における住環境を形 成するシステムを特徵的な街路形態との対応性から明らかにする一 連の研究の一つとして位置付けられる。その中にあって本研究の独
* パナホーム㑣) 修士(工学)

** 東京工業大学理工学研究科 助手.工修

*** 東京工業大学理工学研究科 教授・工博
PanaHome Corporation, M. Eng.

Research Assistant, Tokyo Institute of Technology, M. Eng.

Prof., Tokyo Institute of Technology, Dr. Eng. 
自性は、マカオにおける袋小路を核とした住環境の形成という形態 的特異性と、都市全体としては住居・商業という用途が混在しなが らも部分的には互いが巧みに住み分けることによってその共存を可 能とするマカオの生態的特異性を研究の主眼に置くところにある。

また都市空間に関する研究はこれまで多くされてきており、特に 本論文と同じく海外の都市空間を対象にしたものとしては布野らが 行った一連の研究がある*いー8。これらは都市空間におけるその地 域での特徴的な街路構成、街区構成を空間に対する現地での名称な どをもとに原理的に明らかにする研究として興味深いものである が、都市空間の住環境としての側面に主眼をおいた本研究とは立場 が異なる。都市における住環境に関する研究としては中庭空間を中 心とした住戸のかたまりを単位としたもの*り・いがあるが、いずれ も利用形態や行動パタンをもとに分析したものであり、物理的な分 析に主眼をおいた本研究とは立場が異なる。

\section{2. 研究の対象と方法}

\section{$2-1$. 対象の概要}

中国南部の大河珠江の河口西岸、香港の西約 $70 \mathrm{~km}$ に位置するマ カオ*12は1557年のポルトガル人による居留から1.999 年の中国 への返還に至るまで約110年にわたる統治の歴史*13を経て現在に 至る。

マカオにはポルトガル人が居留を始めるまで、半農半漁の小さな 集落が点在するに過ざなかっだは。都市としてのマカオは、ポル トガル人がマカオ半島南部の丘陵地を中心として不整形な迷路状の 街路を建設したのがその始まりとされる*1\%。頃斜の多い地形に尾 根筋、谷筋に沿って主要な街路が敷かれ、袋小路はそこから枝分か れして形成されている*い。20世紀初めに入ると、半島北部の市街 化·既成市街地の区画整理・海岸の大規模な埋め立てによってマ力 オの都市は姿を大きく変える。それでも20世紀以前に建設された 地域の街路体系は、基本的に現在でも継承されていることが1889 年の地図*17 から確認されている。

本研究で対象とする袋小路の概要について説明する。従来の袋小 路は 2 層の住居によって囲われ、血族関倸を基本としたコミュニ ティを形成していたとされる*18。周りを取り囲むレンガ造の住居 は一つの袋小路にしかエントランスをもたない間口イ $\mathrm{m}$ 程度の長屋 式の平面を基本とし、隣の住居と外壁を共有しながら建ち並ぶ。し かし、現在ではこのような従来の姿を完全にとどめる袋小路はほと んど失われ、建物は 5 階建て程度にまで中高層化され、袋小路内に も商店や工場など住居以外の機能が混在してきている。現在はこの ような変化の途中段階にあり、完全に中高層化、商業化した袋小路 がある一方で、従来の姿をとどめる袋小路もあり、またその $2 つ の ~$ 状態が混在した袋小路もみられる。このように近代化した袋小路に おいても、2 階以上は住居であることがほとんどであり、いまだ袋 小路はマカオにおける住環境としての機能を担っているといえる。

本研究はそのような变遷をふまえた視点に立ったものでもあり、 完全にその周辺からは独立した住環境を形成していた古くからの袋 小路という形式が、近代化による中高層建築・商業用途の混在に対 してどのような形で住環境としての機能を維持し続けているかを明 らかにするものでもある。

\section{2-2 対象の選定と研究のフロー}

本研究では、マカオの中心市街のある半島部（図1）において、 20世紀初めまでに都市化されていた範囲を旧市街とし、その中で 現地調査によって得られた152の全袋小路を対象とする。

調査は 2002 年 6 月と同年 9 月の 2 度にわたって行い*19、研究 対象とした袋小路に対して、袋小路の平面形状、周辺建物の形状、 表出物などについてデー夕を作成した（図2）。

本研究は第 3 章において袋小路を形成する 3 つのレベルを定義 し、個々の袋小路についてそれぞれのレベルから段階構成を示す。

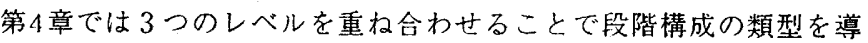
き、それぞれのレベル相互の働きにより袋小路の段階構成にみられ

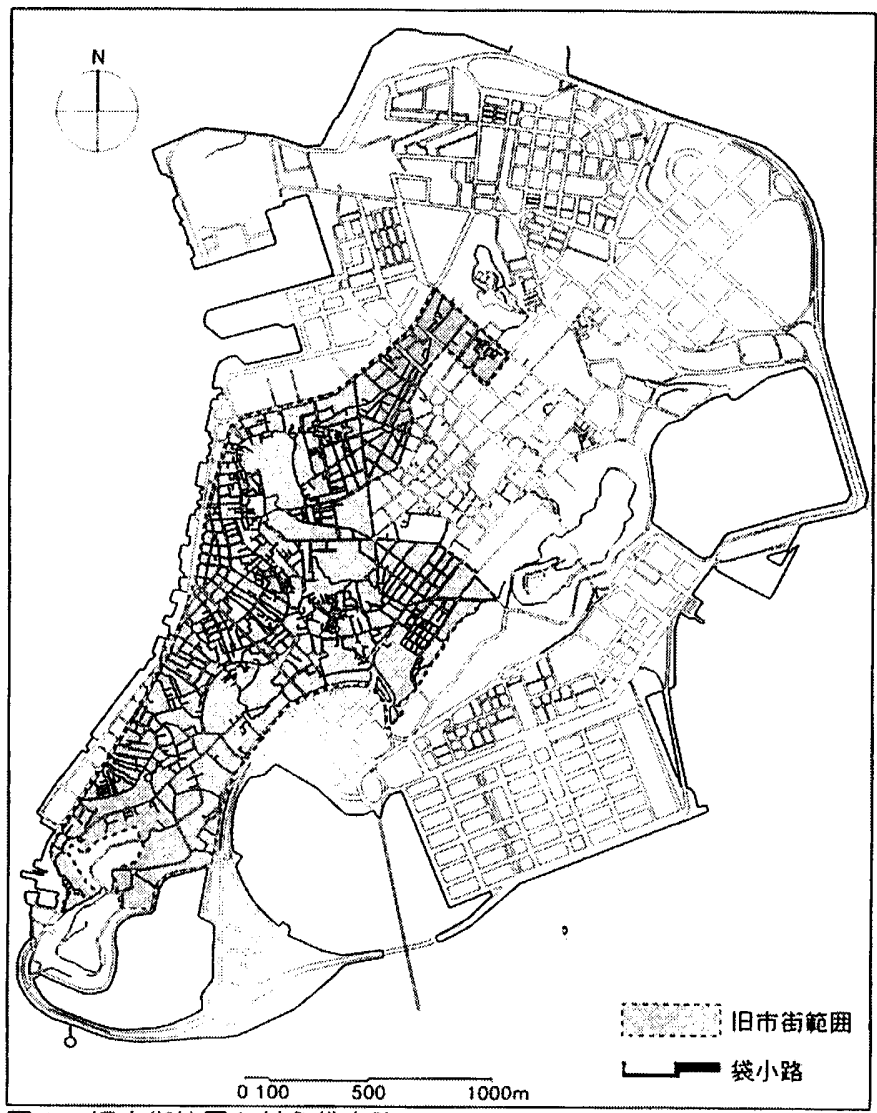

图 1 旧市街簕囲と対象撼小路

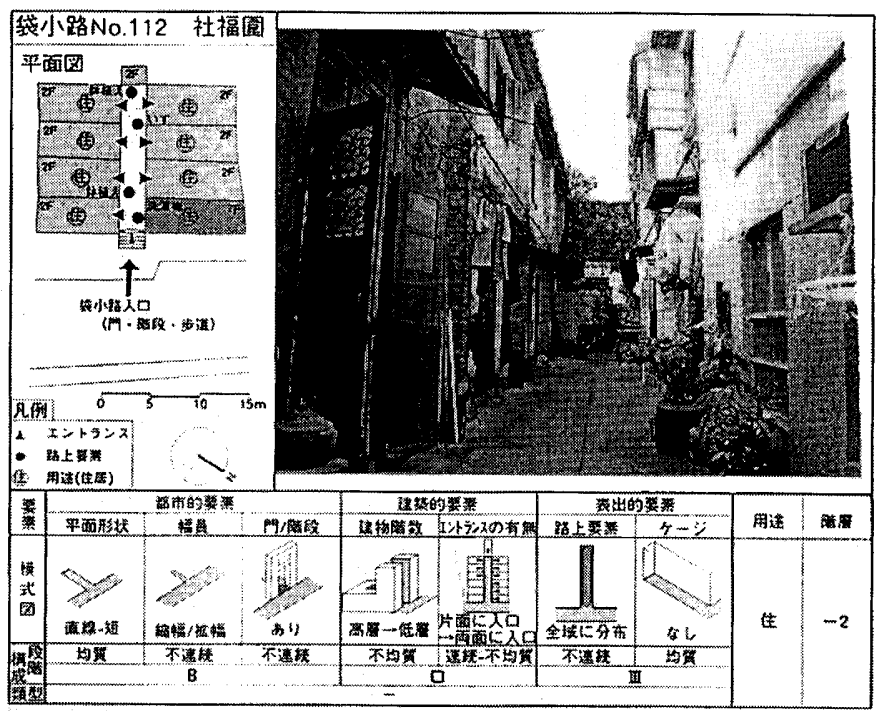

図2 袋小路の分析例 
る作用を示す。第う章では袋小路の段階構成と全街路体系内での位 置付け、また袋小路を構成する建物の用途との関倸から袋小路にお ける段階構成の般割を明らかにする。

\section{3. 形成要素のレベル別にみた袋小路の段階構成}

\section{3-1. 形成要素と段階構成の定義}

都市を構成する物理的な要素を、それを形成してきたと考えられ る主体によって分類することで、その都市の形成原理の一端を捉え ることができると考える。そこでマカオの袋小路を形成している要 素を、その主体のレベルによって以下のように分類する。

《都市的要素》都市を計画した施政者、またはその袋小路に居 住する複数の人々により、都市的・地域的 - 集団的側面から形成さ れる要素。(平面形状・幅員・閏/階段)

《建築的要素》袋小路を囲う建物の所有者・建設者により、建 築的な側面から形成される要素。(建物階数・エントランスの有無)

《表出的要素》袋小路を囲う建物の居住者・使用者という個人 により、利用的な側面から形成される要素。(ケージ・路上要素)

また袋小路の住環境としての役割に着目した場合、それを成立さ せるための緩衝機能の一つとして袋小路の外部から内部に至るまで の段階構成の存在が考えられる。ここでは、段階構成が形成される 位置として袋小路の入口、袋小路の内部という二段階に分け、それ ぞれの位置における境界となりうる要素の有無によって袋小路が段 階構成をもつものとする（図３）。袋小路の入口においては、境界
がない袋小路を、接続する街路からの環境が変化しないものとして 「連続小、境界がある袋小路を、接続する街路からの環境が変化する ものとして「不連続」とする。袋小路の内部においては、境界がな い袋小路を、袋小路内部での環境が変化しないものとして「均質」、 境界がある袋小路を、袋小路内部での環境が変化するものとして 「不均質」とする。

また、これら双方の位置での組み合わせによって袋小路における

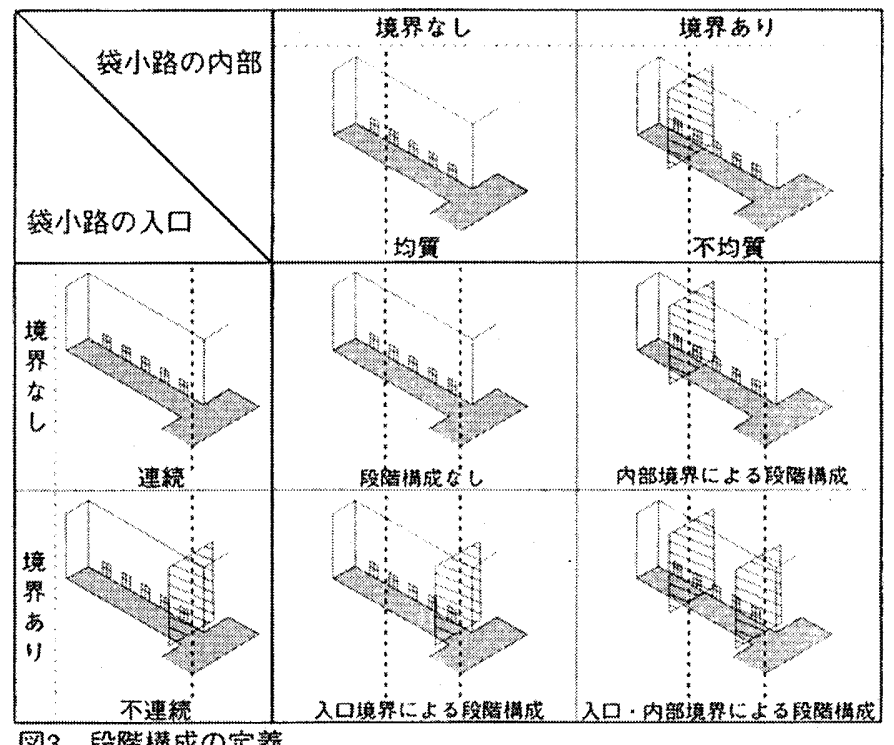

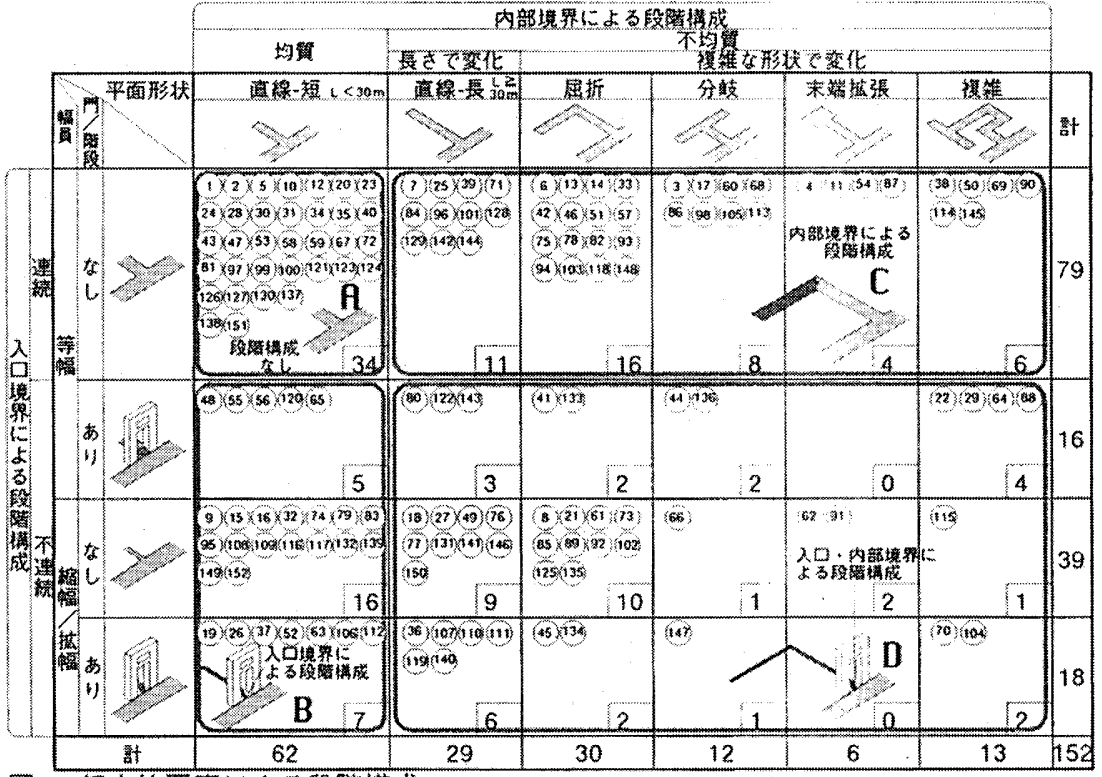

脑4 都市的要案による段階構成
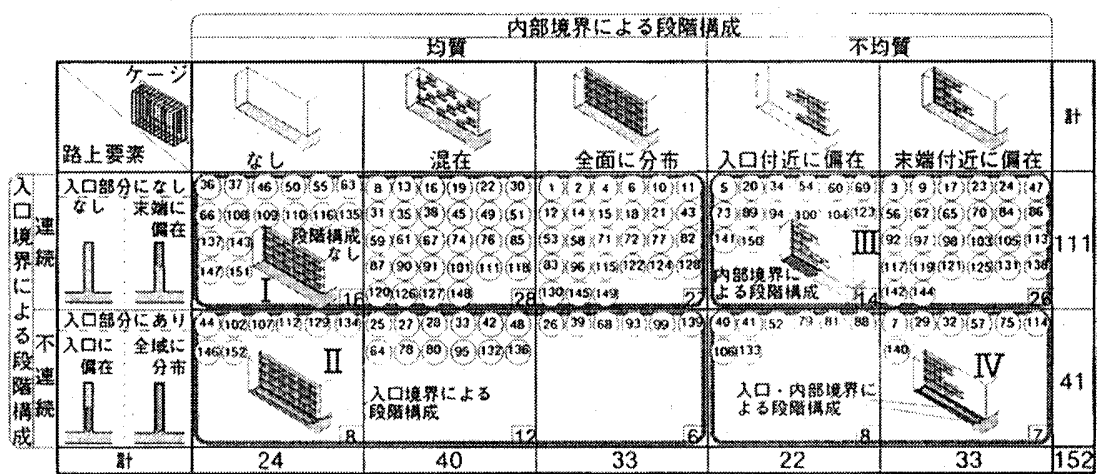

国6 表出的要雩に上る段礕構成

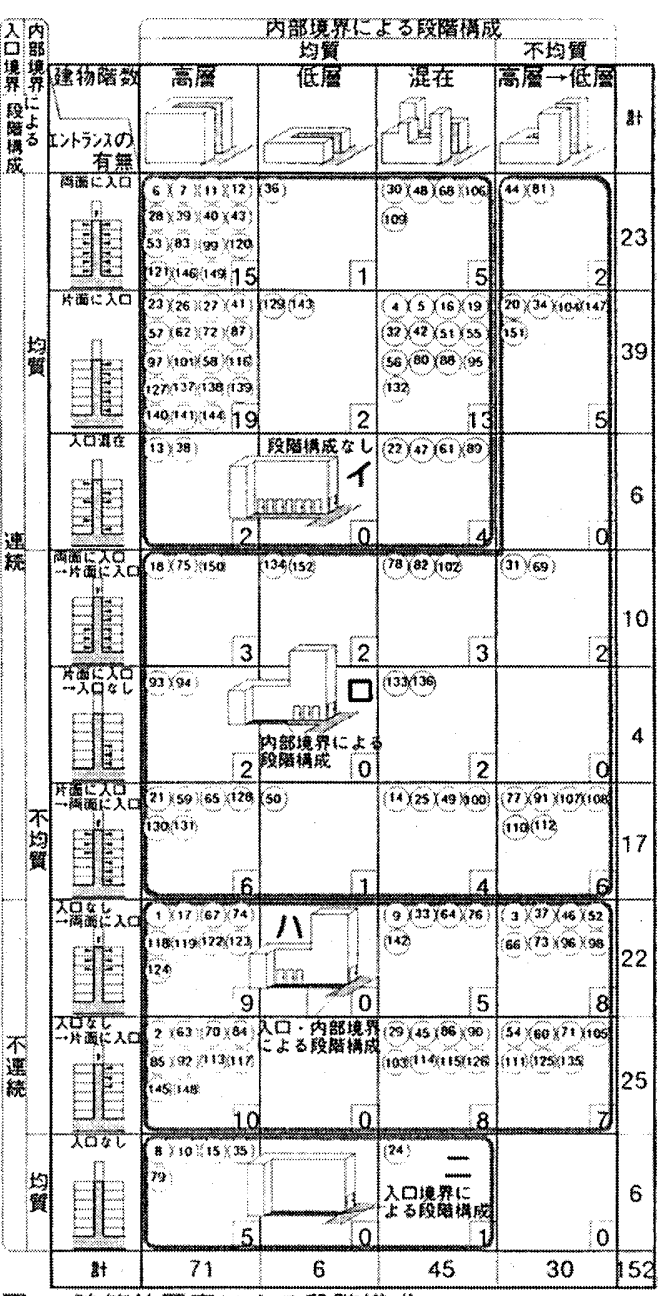

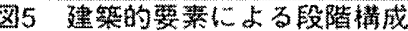


段階構成を 4 種類定義する。

\section{3-2. 都市的要素による段階構成}

都市的要素による袋小路の段階構成を図4 に示す。幅員は、袋小 路が接続する街路に対し等幅の袋小路を連続、拡幅/縮幅のある袋 小路を不連続とし、門/階段は袋小路の入口にいずれもない袋小路 を連続、入口にいずれかがある袋小路を不連続とする。平面形状 は、直線状で短い袋小路を均質、直線状で長い袋小路を内部に暧昧 な境界を形成する袋小路として、また屈折・分畦・末端拡張・複雑 などの形状変化を伴う袋小路を不均筫とする。

これによると、都市的要素において段階構成をもたない月が34/ 152、入口境界による段階構成のBが 28/152、内部境界による段 階構成のCが45/152、入口・内部境界による段階構成のDが45/ 152 であった。全体の約 $3 / 1$ の袋小路がいずれかで段階構成をも つことが分かる。

\section{3-3. 建築的要素による段階構成}

建築的要素による袋小路の段階構成を図5に示す。袋小路に面す る建物のエントランス*が袋小路の入口部分にある袋小路を連続、 入口部分にない袋小路を不連続とし、さらにエントランスの有無が 内部まで連続する袋小路を均算、増加/減少する袋小路を不均質と する。建物階数は、変化しない袋小路、高層と低層が均等に混在す る袋小路を均質、内部で高層から低層に変化する袋小路を不均算と する。

これによると、建築的要素において段階構成をもたないイが61/

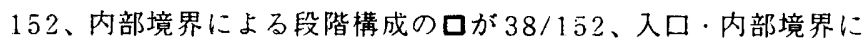
よる段階構成の八が 17/152、入口境界による段階構成の二が $6 /$ 152 であった。全体の約 $2 / 3$ の袋小路がいずれかで段階構成をも つことが分かる。

\section{3-4. 表出的要素による段階搆成}

表出的要素による袋小路の段階構成を図 6 に示す。路上要素*21 は袋小路の入口部分に境界を形成する要素とし、入口部分にない袋 小路を連続、入口部分にある袋小路を不連続とする。これは、袋小 路の入口部分にある路上要素は、接続する街路からの利用者による 境界を形成しているものと考えられるためである。またケージは袋 小路内部で境界を形成する要素とし、分布しない・分布に偏在がみ られない袋小路を均買、袋小路入口付近·袋小路末端付近に偏在す る袋小路を不均筫とする。

これによると、表出的要素において段階構成をもたないIが71/ 152、入口境界による段階構成の Iが26/152、内部境界による段 階構成の III $40 / 152$ 、入口・内部境界による段階構成の IVが $15 /$ 152 であった。全体の約 1/2の袋小路がいずれかで段階構成をも つことが分かる。

\section{4. 袋小路における段階構成の類型}

\section{4-1. 各類型の特徵}

都市的·建築的・表出的という3つのレベルの要素は実際にはそ れぞれが重なり合うことによって一つの㗢きを生み出しているもの であり、そのいずれが機能しているか、またそれがどのように重な り合っているかを分析することによって袋小路の段階構成を明らか にする。そこで、各レベルの要素による袋小路の段階構成を整理 し、マカオの袋小路における代表的な段階構成として 4 つ以上の袋
表1垡小路における段階構成の類型

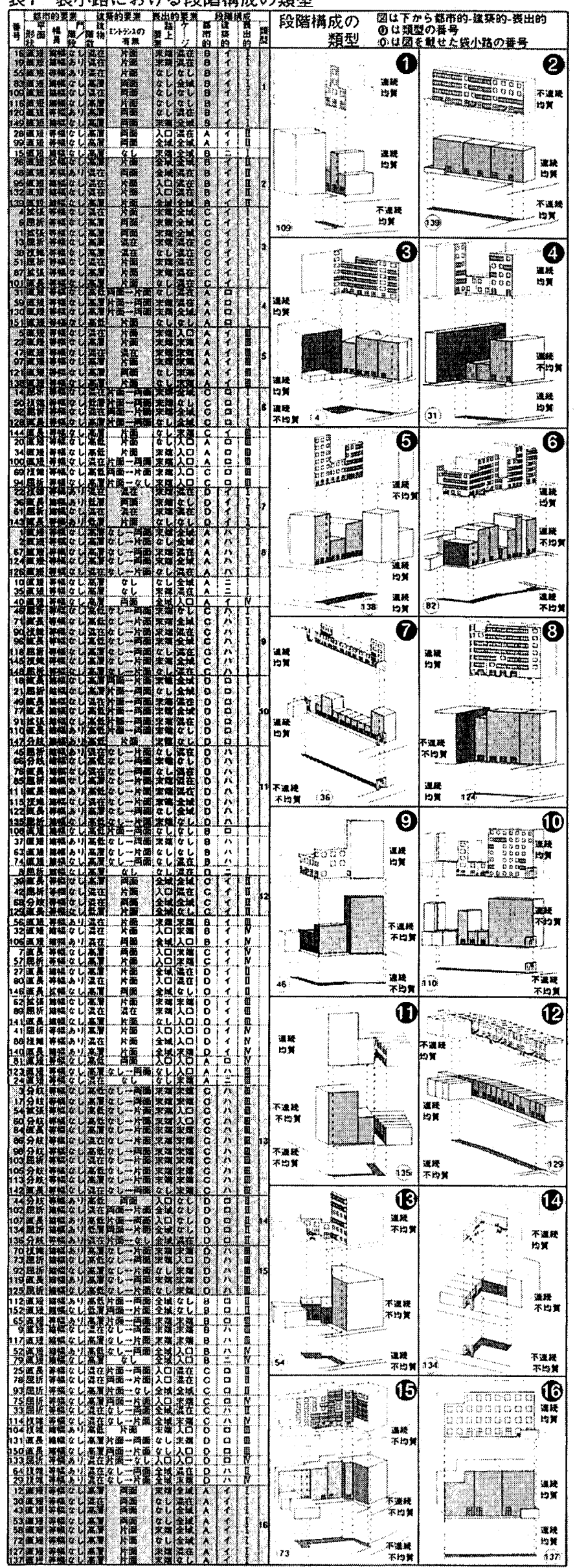


小路で共通の段階構成がみられたものを類型とし、表1にみられる 16 の類型を得た。

袋小路は、住居の他商店や工場など住居以外の機能を含んだ環境 であるが、段階構成の緩衝機能としての側面に着目し、それにより 住環境が形成されるものであると捉えると、16の類型は住環境の 形成のあり方と境界を形成する要素のレベルの関係から図 7 のよう に大別できる。

類型 $1 \cdot 2$ は入口境界による段階構成をもつことにより、袋小路 全体に均質な住環境を形成している。類型 1 は都市的要素により、 類型 2 は都市的要素と表出的要素により境界を持つものである。 従って類型 $1 \cdot 2$ は都市的要素による関与が大きい住環境である。

類型3〜6は内部境界による段階構成を持つことにより袋小路の 奥部にのみ住環境を形成している。類型了は都市的要素により、類 型 4 は建築的要素により、類型 5 は表出的要素により、類型 6 は都 市的要素と建築的要素により境界を持つものである。従って類型 3 〜 6はいずれの要素でも関与がみられる住環境である。

類型 7〜 15 は入口・内部境界による段階構成を持つことにより、 袋小路の全体に段階的に住環境を形成している。類型7は都市的要 素により、類型 8 は建築的要素により、類型 $9 \cdot 10 \cdot 11$ は都市的要 素と建築的要素により、類型12は都市的要素と表出的要素により、 類型 13・14・15 は都市的要素と建築的要素と表出的要素により境 界を持つものである。従って類型 $7 \sim 15$ は都市的要素と建築的要 素による関与が大きい住環境である。

類型 16 は段階構成がなく、住環境を形成しにくいものである。 以上のように、袋小路はレベルや境界の位置の組み合わせによっ て一段階または二段階の住環境を形成していること、また入口、内 部という 2 つ位置で都市的、建築的、表出的という 3 つの要素が 重なり合って袋小路の独立性に強弱を形成していることを明らかに した。

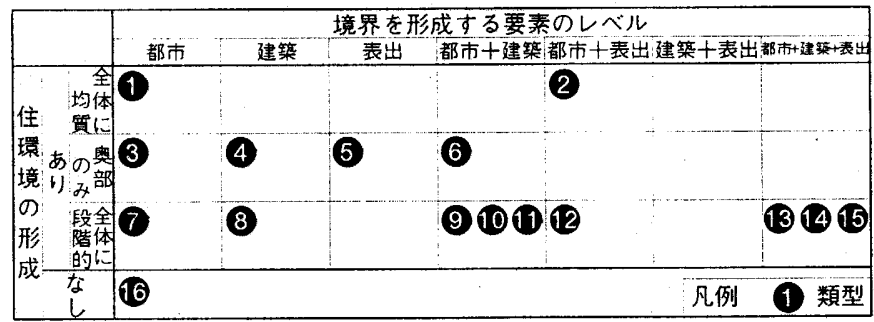

図7 袋小路における段階構成の類型

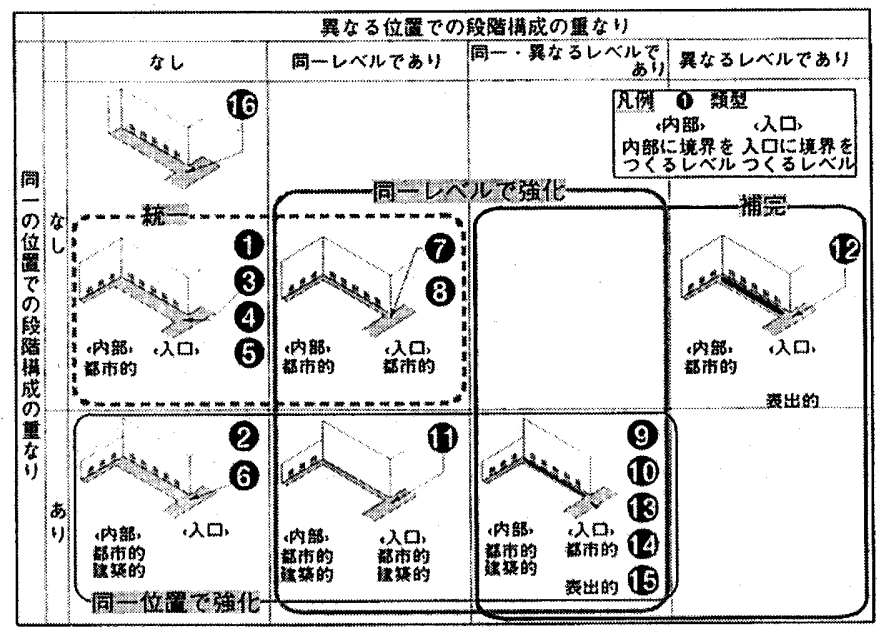

图8 類型間の関係と段笓構成にみられる作用

\section{4-2. 類型間の関係と段階構成にみられる作用}

前節でみられた類型は、段階構成をつくるレベルのそれぞれの位 置での重なり方により図8のようにまとめられる。

類型 $1 \cdot 3 \cdot 4 \cdot 5$ は、単独レベルの要素が入口か内部一方の位置 に境界をつくる段階構成。類型 $2 \cdot 6$ は、境界をつくる要素がいず れかの位置でのみ異なるレベルで重なる段階構成。類型 $7 \cdot 8$ は、境 界をつくる要素が入口と内部とも同一レベルで重なる単独レベルの 要素による段階構成。類型 $9 \cdot 10 \cdot 13 \cdot 14 \cdot 15$ は、境界をつくる 要素が同一の位置での重なり、異なる位置での同一レベルの重なり と異なるレベルの重なりが複合的にみられる段階構成。類型11は、 境界をつくる要素が入口と内部とも同一レベルで重なり、かつそれ ぞれの位置で異なるレベルでも重なる段階構成。類型 12 は、境界 をつくる要素が入口と内部で異なるレベルで重なる段階構成であ る。類型 16 は、いずれのレベルにおいても連続・均質であり、段 階構成をもたない。

図8のまとまりからそれぞれの類型には、境界をつくるレベルの 重なり方により、袋小路の段階構成にみられる作用として以下の 4 つを見いだすことができる。

・単独レベルの要素のみで境界をつくることにより段階構成を統一 する。

·複数レベルの要素がつくる境界が同一の位置で重なることで段階 構成を同一位置で強化する

・入口と内部に境界をつくる要素が同一レベルで重なることで段階 構成を同一レベルで強化する。

·入口か内部一方の境界をつくる要素が異なるレベルで重なること で両方の位置での段階構成をお互いのレベルで補完する。

以上より、袋小路おける住環境の形成は、段階構成にみられるレ ベル間での協同作用によることを表しているものと考えられる。

\section{5. 周辺環境との関係からみた段階構成}

以上のように段階構成が多様な形をとる要因は、その周辺環境に 適応する形でそれぞれの袋小路の要求を満たすことにあるものと考 えられる。そこで段階構成の役割を周辺環境との関係から捉えるた めに、マカオの全街路体系内での袋小路の位置付けと袋小路を囲う 建物の利用として、図9の上うに接続する街路の階層*22 と用途*23 を定義する。またそれぞれのレベルに扔ける袋小路の段階構成と、 その袋小路が接続する街路の階層・袋小路を囲う建物の用途との関 係を表 2 に示す。

階層別に各レペルで優勢な段階構成をみてみると、階層が最も高 位の-1では都市的要素はCの内部境界による段階構成とDの入口・ 内部境界による段階構成、建築的要素は八の入口・内部境界による 段階構成、表出的要素はIの段階構成なしであり、都市的・建築的 要素によって、接続する街路からは 2 段階で独立した環境が形成さ れる傾向がみられる。階層 -2では都市的要素はDの入口・内部境 界による段階構成、建築的要素はイの段階構成なし、表出的要素は Iの段階構成なしであり、都市的要素のみによる 2 段階の段階構成 を形成する傾向が強く、階層 -1 の袋小路よりも接続する街路から の独立性は弱い。階層が最も低位の-3では都市的要素は Cの内部 環境による段階構成、建築的要素はイの段階構成なしと口の内部環 境による段階構成、表出的要素はIの段階構成なしであり、内部で 
は境界をつくるものの入口では境界をつくらず接続する街路からの 環境がそのまま連続する傾向がみられる。

以上より、階層が高位から低位になるに従って袋小路の独立性は 弱まる傾向があることが分かる。これは、階層が低位である袋小路 は、幹線街路からの分岐、折れ曲がりを複数回経るという立地条件 があり、境界要素と同様の機能を備えていると考えられるためであ る。

用途別に各レベルで優勢な段階構成をみてみると、〈住〉では都 市的要素はDの入口・内部境界による段階構成、建築的要素はイの 段階構成なし、表出的要素は II の入口境界による段階構成である。 特に都市的要素では $18 / 19$ とほとんどの袋小路で境界をもち、そ れに表出的要素が加わることで独立性の求められる住環境を形成し ている。〈商〉では都市的要素、建築的要素、表出的要素いずれに

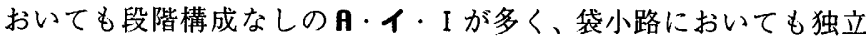
性よりもむしろ開放性が求められる商業環境を形成している。く混 在〉では都市的要素は Cの内部環境による段階構成、建築的要素、 表出的要素は段階構成なしのイ・Iが多く、商業用途の混在により 独立性は弱いものの都市的要素においては境界をつくる傾向がみら れる。〈商住〉では都市的要素は C の内部境界による段階構成と D の入口・内部境界による段階構成、建築的要素は八の入口・内部境 界による段階構成、表出的要素はIの段階構成なしと III の内部境界 による段階構成であり、接続する街路からの独立性が強く、特に内 部に境界をもつ傾向が大きいことから用途の変化に対応して袋小路 の奥部に独立した住環境を形成しているものと考えられる。

以上より、袋小路の段階構成は、接続する街路の階層と用途とい う周辺環境の要求に対応して形成されることを明らかにした。

\section{6. 結譣}

本研究ではマカオの旧市街において袋小路を対象とし、袋小路を 形成する要素の重なり方や周辺環境との関係を考察することによっ

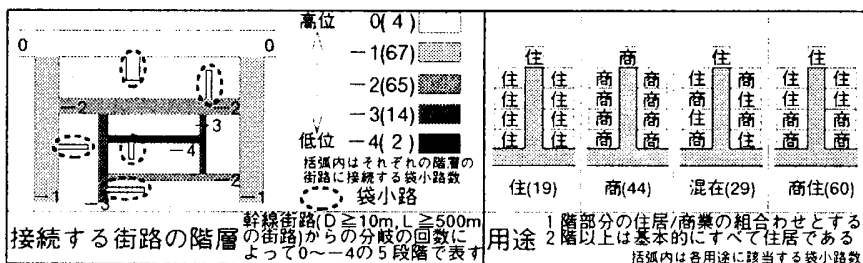

図9接続する街路の階層と用途の定義

表2 踏層・用途との関係からみた袋小路の段階構成

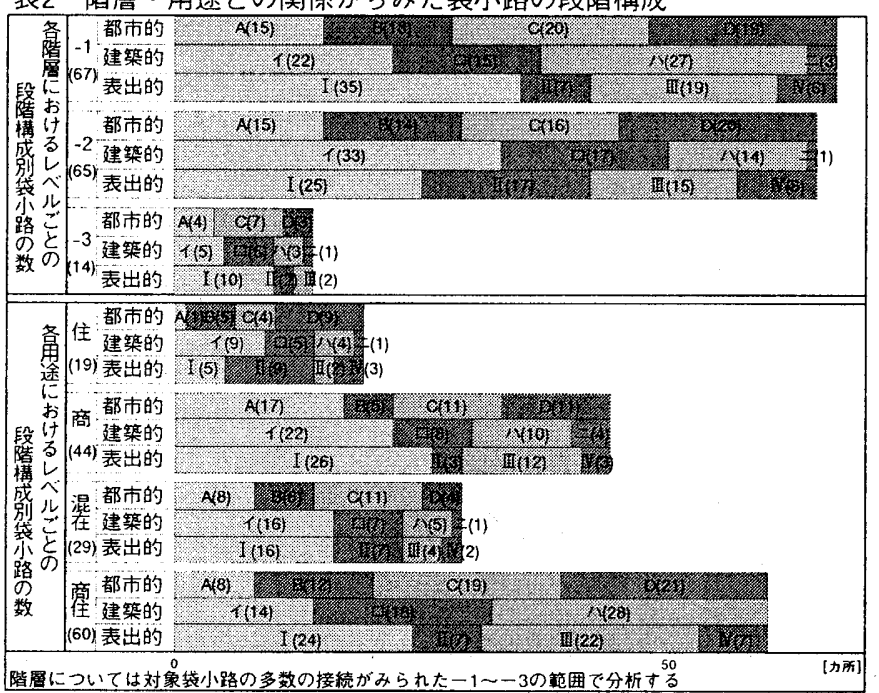

て、住環境を形成する袋小路の段階構成を明らかにした。

第 3 章では、袋小路を形成する要素に対し、都市的・建築的・表 出的という三つのレベルを設定し、それぞれのレベルについて袋小 路の段階構成を明らかにした。

第4章では、三つのレベルの要素による段階構成の重权合わせと して袋小路の段階構成の類型を示した。さらに境界をつくるレベル の重なり方により、統一・同一位置で強化・同一レベルで強化・補 完という袋小路の段階構成にみられる作用を見いだし、袋小路が三 つのレベルの協同作用により段階構成をもつことを明らかにした。

第 5 章では、それぞれのレベルにおける袋小路の段階構成と、袋 小路が接続する街路の階層および袋小路内の用途との関係を示すこ とで、袋小路の段階構成が周辺環境の要求に対応しながら住環境を 形成していることを明らかにした。

以上より、マカオにおける袋小路は段階的に構成され、それに よって住環境を形成していること、またそれが周辺環境の要求に対 応しながら三つのレベルの協同作用によって形成されることを明ら かにした。

謝辞 本研究は住宅総合研究財団平成 14 年度助成を受けて行われ たものである。合わせて感謝の意を記したい。

註

※1 タージ(cage)は、忩やベランダに外部側に㸡り出して設置される、铁 根を鳥かご状に組み立てた骨行き $1 \mathrm{~m}$ 程度の仮設增筑物であり、建物建設後

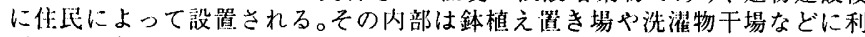
用され、袋小路内外を問わずマカ才全域にわたってみられる。なお、ケージ はマカオの他香港・中国南部などでみられる。

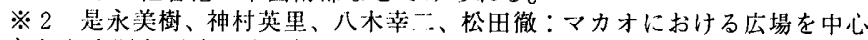
とした空間と用途の連続性一その 1 ・その 2 一、日本建築学会大会学術講演 梗概集、2003 年、p $389 \sim 392$

※3 松田徽、荻野隆博、田辺泰、那須聖、八木幸二：アーメダバード、マ ネクチヨウク地区における建物と外部空間の集合形式、日本建筑学会㖕宙系 論文集、2002.12、No.562、D129～134

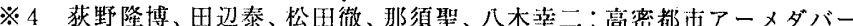
トに㧍ける屋外空間を通してみた集住環境を支えるシステム（その1）（そ の 2 )、日本建筑学会大会学術蓝演梗概集、2001 年、p501 154

※ 5 荻野隆博、長田久美、源辺猛、八木幸二、那須聖、茶谷正洋：ジャん サルメルの伝統的都市住居における空間構成と生活様式（その1) 住居の 緩街空閆と段階棉成、(その 2) 住居の段階的空間構成、日本建啝学会大会 学術講演梗概集、1998 年、p 21 24

※6 布野修司、黄蘭羏、山根周、荒仁、山本直彦、渡辺菊真: ジャイプル の街路体系と街区構成インド調查局作製の都市地図(1925-28年)の分析 その 1、日本建筑学会計画系論文集、1997.9、No.499、p113 119 ※ 7 山根周、布野修訶、荒个、沼田典久、長村英俊：モハッラ、クーチャ、 ガリ、カトラの空間椣成 ラホール旧市街の都市構成に関する研究 その 1、日本建筑学会計画系論文集、1998.11、No.513、p227２34 ※ 8 布野修司、脇出祥尚、青井哲人、牧紀男：チャクラマガラ(インドネ シア・ロンボク鳥）の街区满成 チャクラヌガラの空間構成に関する研究 その 1、日本建筑学会計䛧系論文集、1997.1、No491、p135 - 139 ※ 9 ウスビサコ、宗本順三、吉田哲、設楽亮一：マリ共和国の首都バマコ の居住空問の類型化と空開利用特性についての研究、日本建築学会計画系論 文集、1998.9、No.509、p $97 \sim 104$

※ 10 設楽亮一、宗林順

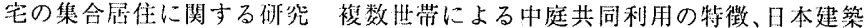
学会計画系論文集、1999.5、N0.519、p115 121

※ 11 ウスビサコ、宗本㮌、吉时哲、設楽亮一：バマコの中庭型在来住 宅の集合居住に関する研究 その 2 時刻による生活行動の行われる場所の 広がりと変化、日本建築学会部画系論文集、1999.8、No.522、p155１62 ※12 正式名称は「中菲人民其和国澳門特別行政区」。公束省珠海市に接导 るマカオ半的とその南の夕イパ島、コロアン島からなる総的皘 21.5 平方キ

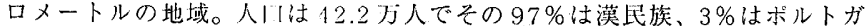
ル人もしくは它の混们である。 
※131514年に初めてマカオに上陸したポルトガル人が、1557年に居留 地をつくつたのがマカ才に扔ける統治の歴必の始まりとされる。キリスト教 勢力の東方への拡大と日本・中国を初めとする極東貿易の樾点とすることが その目的であった。1586年にはポルトガル本国とは独立した自治権を得る ものの、梌中スペインによる統治、日本の鎖国による貿易の中断、南京条約 による対中貿易における特権の失効などにより盛衰を繰り返す。1887年の リスボン誐完青により清朝はマカオをポルトガル領と認め、マカオの永久統 治を諗めるが、1987年に調印された中蔽共同宣言に基づき 1999 年に中国 に返邀された。年の後 50 年間は一国润制度の「中華人民共和国澳門特別行 政区」として現在に至る。

※ 14 参考文献[1 1 2]

※ 15 参考文献[3]p 17

※ 16 マカオの袋小路と地形との関係については現在継続調查、研究中で あり、炏槁以下において報告する予定である。

※17 参考文献[1.1p 21

※ 18 参考文献[1]p 23

※ 19 現地調查はマカオ市政局のFrancisco Vizeu Pinheiro氏の多大なる 協力と教示の下に行われた。

※20 ここではエントランスとは建物につけられる内外の出入口を意味し、 袋小路以外の街路沿いには基本的にはエントランスが連続することから、袋 小路の入口付近に面する建物にエントランスがない場合を袋小路の入口に境 界を形成するものとし、また袋小路内部でエントランスの有無が変化する場 合を袋小路の内部に境界を形成しているものとする。

※21 路上要素としてはいす・鉢植え・洗濉物などの居住機能から、烸品・ 工作機・屋台など哃業機能まで多種にわたる翼素がみられたが、本研究では 袋小路の住環境としての側面に主眼をおいているため、居住機能のみを分析 対象とした。
※22 刘象地域内の最大級規模である幅貝 $1.0 \mathrm{~m}$ 以上、かつ長さ $500 \mathrm{~m}$ 以上

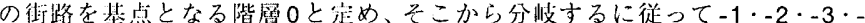
4 と䐓に階層が低くなるものとする。これより袋小路が接続する街路の階層 によってその袋小路の全街路体系内での位置付けを行う。

※23 袋小路に面する室の 1 踏部分の用途加住居加、商店・事務所・工埸 などの蔺業かの組み合わせとして、その用途の大部分が住居のく住、そ穴の用 涂の大部分が游業のく商〉、その用途が住居と阔業が偏在なく混在しているく 混在〉、长の用途が袋小路入口垌辺部に商業、奥部に住居が偏在しているく商 住という 4 種類に定義する。

\section{参考文献}

|1|七ザール・ギーエン・ヌーニエス:マカオの歩み、学芸出版社、1993 [2]東光博英: マカ⿻の歴史南蛮の光と影、大修飭書菬、1998

[3]Paulo Coutinho, Luis Ferreira, Wong Io Fong: Heritage and Urban Planning in Macao, INSTITUTO CULTURAL do Governo da R.A.E. de Macau, 2002

[4]Luis Sa Cunha、Joao Basto, Wong Io Fong:THE HERITAGE OF MACAO Four Centuries of Architectural and Urban History, INSTITUTO CULTURAL do Governo da R.A.E. de Macau、 1998

[5]Luis Sa Cunha:Macau An Open Air Museum macau focus vol.3, Macau International Institute, 2001

|6|Arthur h. Chen:Culture of Metropolis in Macau、澳門特別行政区政府文 化局、 200

[7]馬錦強: 俯瞰 大地中国、澳門地図集 㩐時澳門市政局、2001

|8|熄出浩和: 可能性としてのマカオ 㖟昧都市の位相、雷紀書房、1999 [9]藤森照信、汪坦:全調查東アジア近代の都市と建築、筑摩書房、1996 [1.0]陳述彭、鍾耳順、李崇汾:澳門地図集、澳門基金会、1999

（2004年 3 月 10 日原稿受理，2005年 3 月 22 日採用決定） 